2010-04-01

\title{
Learning and Assessment of Student Communication Skills on Engineering Programs: Some Experiences
}

\author{
Aidan O'Dwyer \\ Technological University Dublin, aidan.odwyer@tudublin.ie
}

Follow this and additional works at: https://arrow.tudublin.ie/engscheleart

Part of the Education Commons, and the Engineering Commons

\section{Recommended Citation}

O'Dwyer, Aidan:Learning and Assessment of Student Communication Skills on Engineering Programs: Some Experiences. IEEE Conference on Transforming Engineering Education: Creating Interdisciplinary Skills for Complex Global Environments, Dublin, April 2010.

This Conference Paper is brought to you for free and open access by the School of Electrical and Electronic Engineering at ARROW@TU Dublin. It has been accepted for inclusion in Conference papers by an authorized administrator of ARROW@TU Dublin. For more information, please contact arrow.admin@tudublin.ie, aisling.coyne@tudublin.ie, gerard.connolly@tudublin.ie.

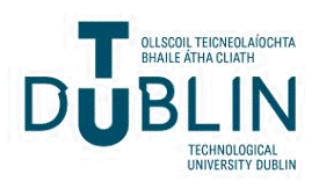




\title{
Learning and assessment of student communication skills on engineering programs: some experiences
}

\author{
Aidan O'Dwyer, \\ School of Electrical Engineering Systems, Dublin Institute of Technology, Kevin St., \\ Dublin 8, Ireland
}

\begin{abstract}
In this contribution, the author reports on, reflects on and evaluates case studies in which the ability to communicate effectively was embedded into modules for which the author had academic responsibility, on both Level 8 (Bachelors) and Level 9 (Masters) engineering programs. The generic competency was developed using formal student presentations, mostly done individually, with a minority done in teams. Peer and tutor assessment of the presentations was employed, following a structured guideline agreed with the students; among other advantages, peer assessment assists in the further development of student analytical skills and professional ethics. The contribution discusses the peer assessment experience, including formal student feedback on the process. The author's experiences are that the learning and assessment method is learner-centered, motivates independent learning, caters to a diverse student background and unlocks previous student work and learning experiences to the benefit of all learners.
\end{abstract}

Keywords-interpersonal and oral communications, peer assessment

\section{INTRODUCTION}

Recently, Engineers Ireland [1] introduced new accreditation criteria for engineering education programs in Ireland, designed to meet the education standard required for the registration of chartered engineers, associate engineers and engineering technicians. In these criteria, more emphasis is given to the development of generic competencies than heretofore. For example, for Level 8 (Bachelors) programs, six program outcomes are defined; two of the program outcomes involve graduates demonstrating generic competencies:

(a) The ability to work effectively as an individual, in teams and in multi-disciplinary settings together with the capacity to undertake lifelong learning;

(b) The ability to communicate effectively with the engineering community and with society at large.

Even before 2007, the author had assessed, in a summative manner on Level 9 (Masters) programs, the ability of engineering students to communicate effectively with their peers, by means of an individual PowerPoint presentation on a relevant engineering topic. The authors experience was that the presentation, and associated peer and tutor assessment, was a valuable learning tool. The learning and assessment method also demonstrated student ability to work effectively as an individual, and raises, in a practical manner, the need for high ethical standards, in this case in the assignment of credit to their peers. Since 2007, the author has extended the approach to learning and assessment on Years 3 and 4 of Level 8 (Bachelors) programs.

A significant literature exists on peer assessment issues, both as applied to student group work (for example, McDermott et al. [2]) and individual student work, which is the main focus of this paper. For example, Falchikov [3] and Morris [4] provide interesting and comprehensive literature reviews on peer assessment issues; some other authors (e.g. Magin and Helmore [5]) focus on the validity of peer and tutor assessment of the oral presentations skills of (engineering) students.

Some authors give more specific advice on how to structure the peer assessment process (e.g. Falchikov [6]), suggesting that the provision of explicit assessment criteria to the peer assessors is important. Other authors (e.g. Kwan and Leung [7]) focus on the agreement (or otherwise) between tutor and peer group assessments, using statistical techniques (including calculation of means and standard deviations). Peer assessment of oral presentations, taking into account factors such as gender, university affiliation, time of day at which the assessment was carried out and participation in the development of the assessment criteria are considered by Langan et al. [8], for example. Other contributions are also of interest (e.g. the peer assessment of poster presentations, as discussed by Orsmond et al. [9]).

The contribution closest to the approach adopted in this paper (both from an assessment methodology and presentation procedure) is that of MacAlpine [10], who considers peer assessments of undergraduate engineering students in a final year option subject.

\section{ASSESSMENT EXPERIENCES}

Peer and tutor assessment of individual student presentations was carried out with students at Level 8, Year 3 $(n=20)$, Level 8, Year $4(n=37)$ and Level $9(n=116)$. The assessment weighting varied from $8.75 \%$ to $15 \%$ of the module credit (Level 8 programs) and, since 2007, from $20 \%$ to $25 \%$ of the module credit (Level 9 programs), depending on the module learning outcomes. Credit was given both for the individual presentation and for individual student feedback to other presenters. Structured guidelines are provided for the assessments, which are available separately from the author. 
Analysis shows that there a borderline $(\mathrm{p}=0.019)$ and no $(p=0.26)$ statistically significant relationship between the average peer assessment result and the tutor assessment result, for the Level 8, Year 3 and Year 4 student cohorts, respectively. On average, students are able to distinguish in a limited way between good and poor work produced by their colleagues. This justifies the decision made that peer assessment should compose a small contribution of the module credit; marks for weaker students tend to be enhanced, with marks for stronger students reduced, by the peer assessment process.

For the Level 9 student cohort, Figure 1 summarizes the relationship between the average peer assessment mark and the tutor assessment mark. Clearly, there is a highly statistically significant positive linear relationship between the average peer assessment result and the tutor assessment result. It is also clear that peers tend to award higher marks than the tutor for presentations that the tutor would assess as weaker; the premium added for an average tutor assessment mark of $65 \%$ is $7 \%$, for example. This difference has a small impact on overall student grades; for example, for the 2009-10 student cohort in one module $(n=60)$, the average and maximum increase per student in overall percentage grade in the module, as a result of this phenomenon, is $0.7 \%$ and $2.3 \%$, respectively.

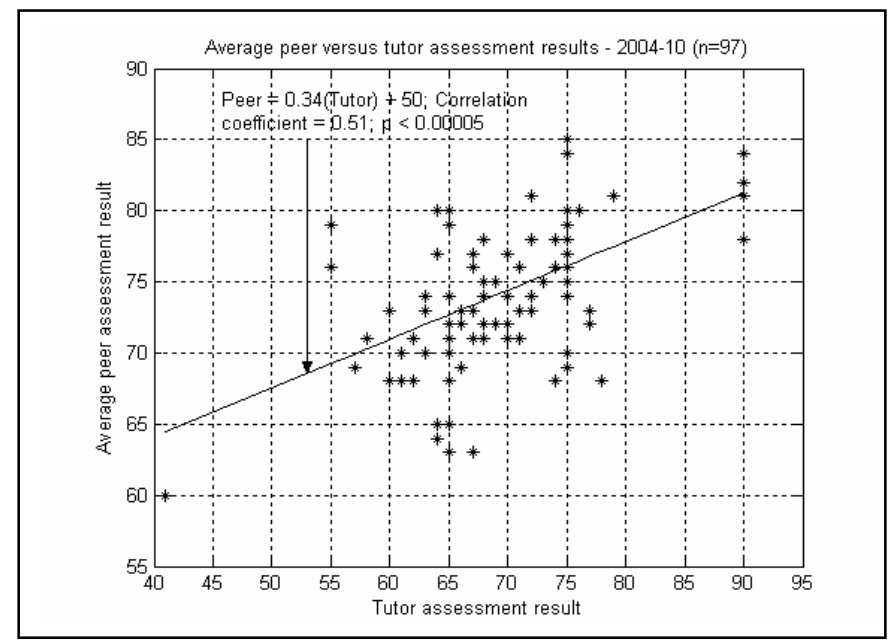

Figure 1. Average peer versus tutor assessment results

\section{StUdENT FEEDBACK ON THE LEARNING AND ASSESSMENT PROCESS}

Formal student feedback was first gathered in 2007-8, using student questionnaires, which are available separately from the author. The questionnaires use a 5-point Likert scale, with 1 corresponding to 'strongly disagree' and 5 corresponding to 'strongly agree'. The questionnaires are constructed with alternating positive and negative questions to avoid directional bias. For example, in the first question, students were asked to indicate whether they thought that the feedback from peer assessment would help their own learning (positive direction). Then, in the second question, they were asked to indicate whether they were uncomfortable assessing the work of their peers. The negative items are reversed for scoring. Overall questionnaire results are provided in Table I.

TABLE I. STUDENT QUESTIONNAIRE RESULTS 2007-10

\begin{tabular}{|c|c|c|c|}
\hline & $\begin{array}{l}\text { Level 8, } \\
\text { Year 3 } \\
(\mathrm{n}=17)\end{array}$ & $\begin{array}{l}\text { Level } 8 \\
\text { Year } 4 \\
\left(\mathrm{n}=43^{\mathrm{a}}\right)\end{array}$ & $\begin{array}{l}\text { Level } 9 \\
\left(\mathrm{n}=48^{\mathrm{b}}\right)\end{array}$ \\
\hline $\begin{array}{l}\text { I think the feedback from peer } \\
\text { assessment will help my own } \\
\text { learning }\end{array}$ & 4.00 & 3.71 & 4.04 \\
\hline $\begin{array}{l}\text { I was comfortable (uncomfortable) } \\
\text { assessing the work of my peers }\end{array}$ & 3.41 & 3.31 & 3.31 \\
\hline $\begin{array}{l}\text { I feel that assessing the work of } \\
\text { my peers will help me to better } \\
\text { improve my own performance in } \\
\text { the future }\end{array}$ & 3.76 & 3.69 & 4.08 \\
\hline $\begin{array}{l}\text { I did (did not) enjoy the process of } \\
\text { peer group assessment }\end{array}$ & 3.18 & 3.50 & 3.47 \\
\hline $\begin{array}{l}\text { I feel that I was able to be } \\
\text { completely objective in marking } \\
\text { the presentations }\end{array}$ & 3.35 & 3.00 & 3.54 \\
\hline $\begin{array}{l}\text { My confidence has increased } \\
\text { (decreased) as a result of peer } \\
\text { group assessment based on } \\
\text { PowerPoint presentation }\end{array}$ & 4.18 & 3.83 & 4.13 \\
\hline $\begin{array}{l}\text { I feel the process of peer group } \\
\text { assessment has developed my own } \\
\text { critical thinking skills }\end{array}$ & 3.65 & 3.57 & 3.79 \\
\hline $\begin{array}{l}\text { I learned more from the peer group } \\
\text { assessment than I would have if } \\
\text { the lecturer only assessed my } \\
\text { presentation }\end{array}$ & 3.47 & 2.86 & 2.96 \\
\hline $\begin{array}{l}\text { I was able to assess others work } \\
\text { with confidence using the criteria } \\
\text { provided }\end{array}$ & 3.76 & 3.41 & 3.56 \\
\hline $\begin{array}{l}\text { I feel positive about assessing the } \\
\text { work of my peers }\end{array}$ & 3.53 & 3.21 & 3.63 \\
\hline $\begin{array}{l}\text { I felt that I was more confident in } \\
\text { making my presentation knowing } \\
\text { that my presentation mark was } \\
\text { largely determined by my peers, } \\
\text { rather than by the lecturer }\end{array}$ & 3.35 & 3.14 & 2.98 \\
\hline $\begin{array}{l}\text { I feel that assessing my peers does } \\
\text { not involve too much work for me }\end{array}$ & 4.35 & 3.71 & 4.06 \\
\hline $\begin{array}{l}\text { The assessment breakdown (in the } \\
\text { marking scheme) is about right }\end{array}$ & 3.71 & 3.29 & 3.43 \\
\hline $\begin{array}{l}\text { I feel I was treated fairly by my } \\
\text { peers in their marking of my } \\
\text { presentation }\end{array}$ & 3.76 & 3.33 & 3.71 \\
\hline $\begin{array}{l}\text { I feel that there was much (little) } \\
\text { learning benefit to me in making } \\
\text { my PowerPoint presentation }\end{array}$ & 3.88 & 3.45 & 4.17 \\
\hline $\begin{array}{l}\text { I learned from the positive (and } \\
\text { less positive) features of the } \\
\text { presentations of others }\end{array}$ & 4.24 & 4.07 & 4.15 \\
\hline $\begin{array}{l}\text { I feel that skills and practice in } \\
\text { presentation are likely (not likely) } \\
\text { to be useful in my working life }\end{array}$ & 4.59 & 4.23 & 3.44 \\
\hline $\begin{array}{l}\text { I think I learned more from the } \\
\text { presentations that I would have } \\
\text { learned if the time was devoted to } \\
\text { lectures and labs }\end{array}$ & 3.41 & 3.60 & 3.51 \\
\hline $\begin{array}{l}\text { Devoting } \mathrm{x} \% \text { of the subject mark } \\
\text { to this activity is about right }\end{array}$ & 4.00 & 3.60 & 3.73 \\
\hline Mean numerical value & 3.77 & 3.52 & 3.67 \\
\hline
\end{tabular}

a. Includes comments from 16 students who presented in teams, rather than individually.

b. Includes comments from 10 students who presented in teams, rather than individually. 
Students were also requested to give general unscripted comments. The two most popular comments under two headings given in the questionnaire are provided in Table II.

TABLE II. STUDENT UNSCRIPTED COMMENTS 2007-10

\begin{tabular}{|l|c|}
\hline What did you like BEST about the assessment? Why? & $n$ \\
\hline Developing presentation skills & 34 \\
\hline $\begin{array}{l}\text { Learned a great deal/good learning benefit/good research } \\
\text { opportunity }\end{array}$ & 32 \\
\hline Total comments given & 114 \\
\hline What did you like LEAST about the assessment? Why? & \\
\hline I am nervous in giving presentations & 9 \\
\hline Difficult to mark others work objectively & 9 \\
\hline Total comments given & 73 \\
\hline
\end{tabular}

\section{DISCUSSION AND CONCLUSION}

The author's experiences are that the learning and assessment method enhances student communication skills and further develops student ability to work effectively, particularly as individuals. More generally, the method is learner-centered, motivates independent learning, caters to a diverse student background, raises awareness of ethics, unlocks previous student work and learning experiences to the benefit of all learners and provides case-study material that may be used on other programs. The author agrees with the conclusion of Kwan and Leung [7] that "although only a moderate degree of agreement has been found between tutor and peer group assessments ... we believe that peer assessments should be introduced to students because the educational benefits of the learning experience may greatly outweigh the risks on an unreliable assessment outcome, particularly if peer assessment contributes only a relatively small part of the formal assessment". Overall, the learning and assessment approach assists in the aim of providing students with the fundamental skills required for life-long self-learning.

\section{REFERENCES}

[1] Engineers Ireland, Accreditation for engineering education programmes, 2007. Available at www.iei.ie (accessed 25 January 2010).

[2] K.J. McDermott, A. Nafalski and Ö. Göl, "Active learning in the University of Southern Australia", Proceedings of the $30^{\text {th }}$ ASEE/IEEE Frontiers in Education Conference, pp. T1B-11 to T1B-15, 2000.

[3] N. Falchikov, "Peer feedback marking: developing peer assessment", Innovations in Education and Teaching International, vol. 32(2), pp. 175-187, 1995.

[4] J. Morris, "Peer assessment: a missing link between teaching and learning? A review of the literature", Nurse Education Today, vol. 21, pp. 507-515, 2001.

[5] D. Magin and P. Helmore, "Peer and teacher assessments of oral presentation skills: how reliable are they?", Studies in Higher Education, vol. 26(3), pp. 287-298, 2001.

[6] N. Falchikov, "Product comparison and process benefits of collaborative peer group and self-assessment", Assessment and Evaluation in Higher Education, vol. 11(2), pp. 146-166, 1986.

[7] K.P. Kwan and R.W. Leung, "Tutor versus peer group assessment of student performance in a simulation training exercise", Assessment and Evaluation in Higher Education, vol. 21(3), pp. 205-214, 1996.

[8] M.A. Langan et al., "Peer assessment of oral presentations: effects of student gender, university affiliation and participation in the development of assessment criteria", Assessment and Evaluation in Higher Education, vol. 30(1), pp. 21-34, 2005.

[9] P. Orsmond, S. Merry and K. Reiling, "The importance of marking criteria in the use of peer assessment", Assessment and Evaluation in Higher Education, vol. 21(3), pp. 239-250, 1996.

[10] J.M.K. McAlpine, "Improving and encouraging peer assessment of student presentations", Assessment and Evaluation in Higher Education, vol. 24(1), pp. 15-25, 1999. 